Reprod. Nutr. Dévelop., 1986, 26 (6), 1219-1239.

\title{
Endocrine regulation of postpartum ovarian activity in cattle : a review (1)
}

\author{
Ch. HANZEN
}

Faculté de Médécine Vétérinaire, Université de Liège. Service d'Obstétrique et des Troubles de la Reproduction, Rue des Vétérinaires 45, 1070 Bruxelles, Belgique.

Summary. The problem of postpartum anoestrus is a real one because it results in prolongation of the time between calvings. The interval between the calving and resumption of cyclic ovarian activity depends on several factors, i.e., amount of feeding before and after parturition, level of milk yield, age of the animal, calving difficulty, presence of a bull in the herd, season and its photoperiodism and particularly the suckling or lactating status of the cow. The anoestrus period is longer in suckled cows (30 to 110 days) than in milked cattle (20 to 70 days).

The physiology of the hypothalamic-pituitary-ovarian axis is still far from clear. Nevertheless, some events are very well demonstrated. The pulsatile release of $\mathrm{LH}$ and $\mathrm{GnRH}$ and the pituitary sensitivity to $\mathrm{GnRH}$ increase gradually after calving. They are inhibited by suckling, which acts more on $\mathrm{LH}$ and $\mathrm{GnRH}$ release than on their synthesis. Suckling or the presence of a calf can exercise its action via oestrogens. Suckling inhibits oestrogen synthesis by follicular cells and diminishes their feed-back positive effect on the hypothalamic-pituitary axis. The suckling effect depends on oestrogen concentrations and on time after calving. The progressive LH release induces the synthesis of progesterone. After calving, the first luteal phase is shorter and the progesterone plasma concentrations are lower than what is observed during a normal cycle. Amongst some hypotheses proposed, premature luteolysis induced by uterine prostaglandins offers a new and very interesting field of research related to the utero-ovarian relationship after calving. The effects of $\mathrm{FSH}$, prolactin and glucocorticoids hormones are much less understood.

\section{Clinical aspects of postpartum anoestrus.}

Clinically, the postpartum period is characterized by a period of behavioural anoestrus, the duration of which differs in different breeds.

If the detection of oestrus is optimal, anoestrus lasts for 20 to 70 days in dairy cows (Graves et al., 1968 ; Callahan et al., 1971 ; Schams et al., 1978 ; Pirchner et al., 1983 ; Richardson et al., 1983 ; Etherington et al., 1984). This period is highly variable in suckled cows and lasts from 30 to 110 days (Wiltbank and Cook 1958 ; Oxenreider 1968; Graves et al., 1968 ; Casida et al., 1968 ;

(1) Work supported by I.R.S.I.A. (Institut pour I'Encouragement de la Recherche dans I'Industrie et l'Agriculture.) 
Short et al., 1972 ; Nancarrow et al., 1977 ; Holness et al., 1978 ; Wettemann et al., 1978 ; Short et al., 1979 ; Dunn and Kaltenbach, 1980 ; Kesler et al., 1980 ; Randel, 1981 ; Montgomery, 1982 ; Peters and Riley, 1982 . Jainudeen et al., 1982/1983 ; Bastidas et al., 1984 ; King and Mc Leod, 1983/1984 ; Hansen and Hauser, 1984 ; Montgomery et al., 1985).

Assay of progesterone in plasma or milk has shown that $88 \%$ of animals of dairy breeds have an luteal activity present by 35 days after calving (Ball and Lamming, 1983) and $95 \%$ within 50 days (Bulman and Lamming, 1978). According to different authors, the first rise of progesterone appears between 16 and 69 days after calving in dairy cows (Webb et al., 1977, 1980 ; Pirchner et al., 1983) and between 56 and 96 days in suckled cows (Fonseca et al., 1980 ; Peters and Riley 1982 ; Jainudeen et al., 1982/1983; Montgomery et al., 1985).

It is possible to detect ovarian follicles by rectal palpation in both milked and suckled cow from the second week after calving (Saiduddin et al., 1968 ; Callahan et al., 1971 ; Kesler et al., 1979 ; Webb et al., 1980; Kesler et al., 1980 ; Stevenson et al., 1983). The size of the follicles increases during the subsequent weeks. But in the suckled cow, there is generally an absence of follicular development until the final stage, namely ovulation.

\section{Factors affecting postpartum anoestrus.}

In our European agricultural areas, an average 12-month calving interval is generally considered as the ultimate goal of economic efficiency in cattle reproduction. In both suckled and milked cows, postpartum anoestrus is a paramount obstacle affecting this goal.

The length of the anoestrus period is variable and depends on several factors.

Most authors admit that before or after calving, extended periods of over- or underfeeding of cows (10 to $20 \%$ of the required needs) can affect ovarian function and consequently the duration of postpartum anoestrus (Wiltbank et al., 1962, 1964 ; Dunn et al., 1969 ; Lammond, 1970 ; Corah et al., 1975 ; Whitman et al., 1975 ; Duffour, 1975 ; Holness et al., 1978 ; Carstairs et al., 1980 ; Dunn and Kaltenbach, 1980 ; Gauthier and Thimonnier, 1982 ; Peters and Riley, 1982 ; King and Mc Leod, 1983/1984; Rutter and Randel, 1984). Some authors have found that overfeeding improves ovarian (Wiltbank et al., 1962, 1964 ; Hansen et al., 1982) or pituitary (Beal et al., 1978 ; Jordan and Swanson, 1979 ; Lishman et al., 1979 ; Moss et al., 1982) function. Others have found no relation between feeding and the ovarian (Lishman et al., 1979 ; Carstairs et al., 1980) or pituitary (Hill et al., 1970 ; Dunn et al., 1974 ; Spitzer et al., 1978 ; Haresign, 1981 ; Rutter and Randel, 1984) activity.

Little is known about the mechanism under which diet exerts its effect. It is conceivable that feeding influences the ovarian response to gonadotropins (Gombe and Hansel, 1973). There was a positive correlation between the degree of fatness of an animal and the plasma concentration of $17 \beta$-oestradiol, 7 weeks after calving (Lishman et al., 1979).

Feeding affects the release of luteinizing hormone (LH) and subsequent luteal function (Dunn et al., 1974 ; Spitzer et al., 1975 ; Apgar et al., 1975 ; Beal et al., 
1978). It has been observed that the release of $\mathrm{LH}$ induced by gonadotropin releasing hormone $(\mathrm{GnRH})$ injection was greater in underfed heifers (Beal et al., 1978 ; Gauthier and Mauleon, 1983), underfed ewes (Haresign, 1981) and underfed rats (Campbell et al., 1977) than in normally fed controls. Other reports have failed to record any difference (Cummins et al., 1975 ; Beal et al., 1978) or have noted a lower release of LH (Lishman et al., 1979 ; Jordan and Swanson, 1979 ; Echterkamp et al., 1982).

In the same way, underfed animals after calving have lower plasma (Terqui et al., 1982 ; Echterkamp et al., 1982 ; Gauthier et al., 1983) or pituitary LH concentrations (Beal et al., 1978). On the contrary, overfeeding does not induce variations in $\mathrm{LH}$ plasma concentrations or in pituitary response to $\mathrm{GnRH}$ (Rutter and Randel, 1984).

These contradictory results may be due to differences between studies in the nature of feed treatments, i.e., the quantitative or qualitative aspects of the ration given to or absorbed by the animal. In general, the amount of food actually absorbed by the animal in connection with the state of its own reserves has not been considered. Now it appears that animals which remain in good condition after calving have, irrespective of the rations received, higher LH plasma concentrations and a greater pituitary response to $\mathrm{GnRH}$ and consequently a shorter calving - first oestrus interval (Gauthier et al., 1983 ; Rutter and Randel, 1984).

Some workers have reported a positive relationship between milk yield and time to first oestrus or ovulation (Marion and Gier, 1968). The duration of anoestrus also depends on the age of the animal. Heifers have a longer calvingfirst oestrus interval than pluriparous cows (Germ Plasm Evaluation Program, 1975, King and Mc Leod, 1983/1984; Tervit et al., 1977). It also depends on calving difficulty. Dystocia and retained placenta, both of which extend the duration of uterine involution, reduce the rate of pregnancies 100 days after calving (Laster et al., 1973) and result in a longer acyclic period after calving (Erb et al., 1958). The presence of a bull in a herd reduces the time before resumption of cyclic activity (male effect) (Zalesky et al., 1984).

Season or photoperiod (Tucker, 1982) also changes the duration of anoestrus after calving (Thibault et al., 1966 ; Montgomery et al., 1980). The longer the duration of illumination at the time of calving, the shorter the duration of anoestrus (Bulman and Lamming, 1978 ; Peters and Riley, 1982 ; Hansen and Hauser, 1983). Animals calving between May and November have a calving-first ovulation interval significantly shorter than those calving between December and April (Lamming et al., 1981; Peters and Riley, 1982; King and Mc Leod, $1983 / 1984)$. This effect is even more important in primiparous than in pluriparous animals. It is also increased by an inadequate diet (Hansen and Hauser, 1983 ; Montgomery et al., 1985). How this effect works is still rather vague. Higher plasma LH (Mc Natty et al., 1984) and prolactin concentrations (Munro et al., 1980 ; Mc Natty et al., 1984) in summer than in winter could be the explanation, though it is not corroborated by some authors (Hansen and Hauser, 1984). Moreover feeding factors can also have a direct or indirect effect upon the process. 
The suckling or lactating status of the animals must be considered as the determining factor. It is unanimously admitted that suckling induces a lengthening of the calving-first oestrus interval (Clapp, 1937 ; Graves et al., 1968 ; Morrow et al., 1969 ; Short et al., 1972 ; Randel and Walker, 1976 ; Edgerton, 1980). This interval is shortened by early weaning (Smith and Vincent, 1972 ; Laster et al., 1973 ; Bellows et al., 1974 ; Carter et al., 1980) or by a temporary suspension (48 to $72 \mathrm{hr}$ ) of suckling (Smith et al., 1979 ; Dunn et al., 1985).

This influence depends on the intensity of the mammary stimulation. According to some authors (Wettemann et al., 1978) but not to others (Peters and Riley, 1982), a cow suckling two calves will have a longer anoestrus (96 days vs 67 days) than a cow suckling only one calf. It also depends on the duration and the frequency of this stimulation (Kaiser, 1975). As a matter of fact, the duration of anoestrus is longer when access to the mammary glands is ad libitum than if it is restricted to one or a few daily periods (Carruthers and Hafs, 1980 ; Montgomery, 1982 ; Randel and Walker, 1976).

\section{Hormonal mechanisms of postpartum anoestrus.}

Several steroid or peptide hormones are directly or indirectly involved in the physiology of the hypophysis and the hypothalamus, the main centers regulating reproduction.

\subsection{Luteinizing hormone $(L H)$.}

Pregnancy has an inhibitory effect on the sensitivity of the pituitary to hypothalamic GnRH (Schallenberger et al., 1978).

The sensitivity of the hypophysis to $\mathrm{GnRH}$ and $\mathrm{LH}$ plasma concentrations gradually increases after calving. The same holds true for $\mathrm{GnRH}$ pulsatile release which increases from $0-0,25$ pulse an hour to $0,25-1,25$ pulse an hour (Echterkamp and Hansel, 1973; Kesler et al., 1977 ; Webb et al., 1980 ; Carruthers et al., 1980 ; Peters et al., 1981 ; Gauthier et al., 1982 ; Humphrey et al., 1983). These changes are principally emphasized during the days preceding the first increase in progesterone and the first ovulation in dry as well as in lactating or suckling animals. In addition, $\mathrm{LH}$ concentrations in suckled cows are lower than those in milked or non suckled postpartum cows (Short et al., 1972 ; Humphrey et al., 1976 ; Webb et al., 1977 ; Kesler et al., 1977 ; Schallenberger et al., 1978 ; Fernandes et al., 1978 ; Stevenson et Britt, 1979 ; Carruthers and Hafs, 1980 ; Carruthers et al., 1980 ; Rawlings et al., 1980 ; Webb et al., 1980 ; Foster et al., 1980 ; Peters et al., 1981 ; Ramirez-Godinez et al., 1982 ; Azzazi et al., 1983).

The time of appearance of this pulsatile release and of pituitary sensitivity varies according to breed. In dairy cows, the pulsatile release of $\mathrm{LH}$ and the sensitivity of the pituitary to hypothalamic $\mathrm{GnRH}$ appears 10 days after calving and is greater between 12 and 15 days after calving (Echterkamp and Hansel, 1973 ; Kesler et al., 1977, 1979 ; Peters et al., 1981). On the other hand, in suckled cows, suckling induces a difference in the time of appearance and 
intensity of this response, extending up to 20-30 days after calving (Radford et al., 1978 ; Carruthers et al., 1980 ; Irvin et al., 1981 ; Peters et al., 1981).

But neither the mechanism by which suckling interferes with the hypothalamic-hypophyseal axis, nor the nature of specific stimuli required to produce this effect are well-defined. Recent work has suggested that mechanical manipulation of teats does not in itself constitute an exteroceptive stimulus capable of altering LH release patterns in the cow (Williams et al., 1984). It is possible that other factors such as physical presence of a calf or social interaction are necessary in order for teat stimulation to be effective.

Suckling may have an effect at three levels.

It reduces the frequency (Carruthers and Hafs, 1980 ; Walters et al., 1982a ; Edwards, 1985) and amplitude of LH release (Radford et al., 1978 ; Carruthers and Hafs, 1980 ; Troxel et al., 1980 ; Webb et al., 1980 : Peters et al., 1981), pituitary sensitivity to $\mathrm{GnRH}$ (Carruthers et al., 1978 ; Smith et al., 1981) and pulsatile release of $\mathrm{GnRH}$ by the hypothalamus (Carruthers et al., 1980 ; Walters et al., 1982c ; Schallenberger and Peterson, 1982).

The inhibitory effect of suckling on resumption of cyclic activity after calving acts more on the $\mathrm{LH}$ and $\mathrm{GnRH}$ release and action mechanism than on their synthesis. Many demonstrations support this proposition.

Pituitary concentrations of LH (Saiduddin et al., 1968 ; Graves et al., 1968) and hypothalamic concentrations of GnRH (Carruthers et al., 1978) are similar in both milked and suckled cows. Suckling is capable of inhibiting the positive effect of endogenous or exogenous oestradiol on the release of pituitary LH (Nancarrow et al., 1977 ; Short et al., 1979 ; Stevenson et al., 1983).

Temporary weaning $(48 \mathrm{hr})$ induces an increase of the plasma $\mathrm{LH}$ concentrations (Smith et al., 1977 ; Walters et al., 1982b) which decrease to precalf removal concentrations within $4 \mathrm{hrs}$ of calf return (Walters et al., 1982d). It also induces an increase of the follicular concentrations of $\mathrm{LH}$ receptors (Walters et al., 1982a). Calf removal stimulates an increase in $\mathrm{LH}$ concentration by increasing LH pulse frequency but the induced activity appears to be in relation to LH plasma concentrations and pulse frequency before calf removal (Edwards, 1985).

Suckling not only delays but also reduces the amount of $\mathrm{LH}$ released in response to $\mathrm{GnRH}$ injection. Temporary removal enhances over time the amount of $\mathrm{LH}$ release induced by $\mathrm{GnRH}$ injection (Dunn et al., 1985).

The number of animals, whether being milked or suckled, which respond positively to injection of $\mathrm{GnRH}$ or oestradiol increases during the postpartum period. On the other hand, suckled cows are less likely to respond by LH release after injection of oestradiol or GnRH than milked cows during the first 15 days after calving. This difference diminishes during subsequent weeks (Schams et al., 1973 ; Britt et al., 1974 ; Kesler et al., 1977 ; Webb et al., 1977 ; Schallenberger et al., 1978 ; Carruthers et al., 1980 ; Smith et al., 1981 ; Walters et al., 1982c).

At last, as well as a diminution in the interval between injection of oestradiol or $\mathrm{GnRH}$ and the $\mathrm{LH}$ peak, there is also an increase in the amplitude of this peak during the first 4 weeks after calving (Stevenson et al., 1983 ; Azzazi et al., 1983). The magnitude of the $\mathrm{GnRH}$-induced release of $\mathrm{LH}$ was directly proportionnal to 
follicular diameter (Smith et al., 1983 ; Lishman et al., 1979) and oestrogen concentrations in postpartum cattle (Fernandes et al., 1978).

\subsection{Follicle stimulating hormone (FSH).}

Concentrations of FSH vary in an unpredictable manner (Schams et al., 1978 ; Manns et al., 1983) but tend to increase during the first few days after calving (Webb et al., 1980 ; Peters et al., 1981).

Suckling does not affect FSH plasma concentrations (Carruthers et al., 1980 ; Convey et al., 1983) or the number of ovarian receptors to FSH (Walters et al., 1982a). It seems that during the early days of the postpartum period, the role of this hormone is of a facilitating or permissive nature (Webb et al., 1980 ; Walters et al., 1982c ; Peters and Lamming, 1984) because it induces the formation of $\mathrm{LH}$ receptors on granulosa cells under influence of oestrogen (Richards et al., 1976).

\subsection{Oestrogens.}

Concentrations of oestrogens (17 $\beta$-oestradiol and oestrone) in blood plasma progressively increase toward the end of pregnancy and are at their highest 24-48 hours before calving (Smith et al., 1973 ; Arije et al., 1974 ; Stellflug et al., 1978). Peripheral levels of oestradiol- $17 \beta$ fall after calving and then fluctuate considerably before first ovulation (Pope, 1982).

Oestrogens such as $17 \beta$-oestradiol and to a lesser extent oestrone (Azzazi and Garverick, 1984) are involved in the effects of suckling on the hypothalamohypophyseal axis. In the hypothalamus, suckling increases the threshold of sensitivity to the negative retro-action of oestradiol on the tonic center (Acosta et al., 1983). Suckling inhibits oestrogen synthesis by the follicular cells (Bellin et al., 1984) for a few days but not for three weeks after calving (Walters et al., 1982a). This fact is important because in rats it was demonstrated (Richards et al., 1976) that follicular sensitivity to gonadotropins depends partly on their oestrogen and androgen concentrations.

In the pituitary, suckling diminishes the LH response to exogenous oestradiol (Short et al., 1979). Oestrogens have a positive effect on the amplitude of the LH peak and on $\mathrm{LH}$ release induced by injection of $\mathrm{GnRH}$. These effects may occur by an increase in the rate or amplitude of $\mathrm{GnRH}$ secretion or an increase in pituitary sensitivity to $\mathrm{GnRH}$ stimulation (Zolman et al., 1974 ; Yen et al., 1974 ; Kesler et al., 1977 ; Beck et al., 1978 ; Hsueh et al., 1979 ; Zaied et al., 1980 ; Kesner et al., 1981 ; Azzazi et al., 1983 ; Peters, 1984).

This effect depends on the dose of oestrogens. High doses $(10 \mathrm{mg})$ of oestradiol benzoate inhibit the pituitary response to $\mathrm{GnRH}$ (Barraclough, 1973 ; Manns and Richardson, 1976) and low doses increase this response (Hobson and Hansel, 1972). It also depends on the right time of injection in relation to calving (Stevenson et al., 1983) and on the period of injection. In ovariectomised ewes treated (for a period equivalent to that of gestation) with a daily dose of oestradiol equivalent to that which occurs during gestation, there is a progressive reduction in the amount of $\mathrm{LH}$ released following $\mathrm{GnRH}$ injection and also a fall in pituitary $\mathrm{LH}$, both these parameters being directly correlated. Simultaneously there was an 
increase in the number of $\mathrm{GnRH}$ receptors in the pituitary (Crowder et al., 1982). After calving, injection of oestrogens for 7 days with a dose sufficient to produce plasma concentrations similar to those present before calving, at first increased and then diminished the amount of $\mathrm{LH}$ released after $\mathrm{GnRH}$ injection, a positive effect which also occurred after the injections had ceased. The decrease of the amount of $\mathrm{LH}$ released may have resulted from a negative effect of oestrogens on $\mathrm{LH}$ synthesis. The second increase could have been due to progressive development of GnRH receptors (Azzazi et al., 1983). Perhaps oestrogens stimulate the synthesis of LH but inhibit its release (Tang, 1977).

\subsection{Progesterone.}

Concentrations of progesterone in the plasma of cows are high throughout gestation. They diminish slowly during the final 3-4 weeks and rapidly 2-3 days before calving (Short, 1958 ; Randel and Erb, 1971 ; Smith et al., 1973).

Milked or suckled cows, 50 to $80 \%$ of the time, have a first luteal phase which is shorter and progesterone plasma concentrations which are lower than observed during a normal cycle (Donaldson et al., 1970 ; Edgerton and Hafs, 1973 ; Humphrey et al., 1976 ; Schams et al., 1978 ; Stevenson and Britt, 1979 ; Kesler et al., 1980 ; Webb et al., 1980 ; Odde et al., 1980 ; Lavoie et al., 1981 ; Peters and Riley, 1982 ; Troxel et al., 1983 ; Pirchner et al., 1983 ; Manns et al., 1983). That hormonal abnormality can result in embryonic mortality (Ramirez-Godinez et al., 1982b ; Troxel et al., 1983).

More precise studies of hormones have shown that two types of luteal activity occur after calving (Troxel et al., 1983). The first is a luteal phase lasting 6-12 days and referred to as the short luteal phase (or SLP), while the second is a luteal phase of normal duration, lasting more than 14 days, but accompanied by progesterone concentrations lower than normal (inadequate luteal phase or ILP). The reason for this is not fully understood. Such a dual possibility has also been observed after GnRH injection (Webb et al., 1977 ; Lishman et al., 1979 ; Kesler et al., 1980 ; Fonseca et al., 1980 ; Sheffel et al., 1980 ; Troxel et al., 1983) or after early weaning (Odde et al., 1980) or limited suckling with (Dunn et al., 1985) or without (Flood et al., 1979) $\mathrm{GnRH}$ injection.

Many hypotheses have been put forward to explain this.

Morphological and endocrine studies (Manns et al., 1983) indicate that these first short-lived corpora lutea are not destroyed by the usual luteolytic process, but by a loss of ability to synthesize progesterone.

The lower FSH plasma concentration before oestrus preceding a short cycle may imply a possible influence of this hormone on the lifespan of the corpus luteum (Ramirez-Godinez et al., 1982a).

Progesterone might be formed by a follicle which has failed to ovulate (Tribble et al., 1973 ; Corah et al., 1974 ; Webb et al., 1980). The absence of differences in LH plasma concentrations observed before or after an oestrus associated with a short cycle does not lead one to a conclusion of an insufficient LH synthesis (Ramirez-Godinez et al., 1982a).

The reduced lifespan might be related to $\mathrm{GnRH}$-induced $\mathrm{LH}$ surge having a short duration (Troxel et al., 1980). However the luteal receptors for LH or the 
number of granulosa cells (Channing et al., 1981) may not be sufficient to give an optimum response to this luteotropic stimulus (Schams et al., 1979). As a matter of fact, while the corpus luteum from cows with regular cycles gives a positive response in vitro to $\mathrm{LH}$ addition in culture medium, this response cannot be observed with a corpus luteum whose formation has been induced by injection of $\mathrm{GnRH}$. This difference may be because the luteal tissues are unable to recognize LH (Kesler et al., 1981). Histological studies have indicated that the response of postpartum corpora lutea to $\mathrm{LH}$ in vitro is similar in all the first three cycles, but that is related to the integrity of luteal tissue at the time of removal (Duby et al., 1985).

These last two observations support the concept of a premature luteolysis.

The presence of a luteolytic agent such as prostaglandin F2 $\alpha$ (PGF2 $\alpha$ ) synthesized after calving by the caruncular uterine tissues (Guilbaut et al., 1981, 1984b) may be responsible for this premature luteolysis and short luteal phase (Troxel and Kesler, 1984b). In fact, concentrations of one of the metabolites of PGF2 $\alpha$, 13, 14 dihydro-15-ceto-PGF (PGFM), increase during and after calving. They reach peak values on days 2 or 3 postpartum and return progressively to a basal concentration by 2 or 3 weeks after calving both in milked (Edquist et al., 1978 ; Thatcher et al., 1980 ; Lindell et al., 1982 : Kaker et al., 1984 : Madej et al., 1984 ; Guilbaut et al., 1984a) and suckled (Troxel et al., 1984) cows. Its concentration decreases after the increase of progesterone in the blood (Lewis et al., 1984). It is generally agreed that PGF2 $\alpha$ is not luteolytic during the first 4 or 5 days of the cycle. Nevertheless, its repeated injection during this period reduces progesterone concentration during the rest of cycle (Beal et al., 1980).

Oxytocin injected (Troxel et al., 1984) or released in response to milking or suckling or the presence of uterine infection (Roberts et al., 1975 ; Lindell et al., 1982 ; Watson, 1984) may be responsible for an increased concentration of PGFM and consequently earlier luteolysis and earlier resumption of a normal luteal phase (Madej et al., 1984). It has also been shown that intrauterine infusion of indomethacin, an inhibitor of prostaglandins synthesis, not only diminishes basal or induced concentrations of oxytocin and of the PGF metabolite (Troxel et al., 1984) but also prolongs the life of corpora lutea induced by $\mathrm{GnRH}$ (Troxel and Kesler, 1984a).

These various observations have led research workers to study the physiological significance of abnormal luteal phases and with experiments to determine the effects of treatments with progestagens or progesterone before an injection of $\mathrm{GnRH}$. Injection of progesterone (25 or $100 \mathrm{mg}$ ) 12 days after calving and $48 \mathrm{hrs}$ before $\mathrm{GnRH}$ injection (Williams et al., 1982) or implantation of norgestomet for 8 days, starting 17 days after calving, followed by an injection of $250 \mathrm{mcg} \mathrm{GnRH} 24 \mathrm{hrs}$ after removal of the implant (Troxel and Kesler, 1984c) have beneficial effects on the amount of progesterone secreted by the corpora lutea thus induced (Ramirez-Godinez et al., 1981 ; Sheffel et al., 1982 ; Pratt et al., 1982). Such pretreatment is without effect if applied 40 days after calving (Troxel et al., 1980).

The mechanism of this effect is still unknown.

A direct effect on the ovary cannot be ruled out, although experiments on 
rats have failed to confirm the role of progesterone in follicular development (Saiduddin and Zassenhaus, 1978).

A local utero-ovarian mechanism has also been proposed. In the first days after calving, the ovary bearing the gestation corpus luteum produces smaller follicles than the contralateral ovary (Lewis et al., 1984). The oestrogen concentration of these follicles is also smaller (Bellin et al., 1984). This has also been observed during the oestrus cycle (Matton et al., 1981 ; Brantmeier et al., 1984). Thirty days after calving, a corpus luteum or a follicle is less often palpated on the ipsilateral ovary than on the contralateral ovary (Lewis et al., 1984), which confirms earlier reports about the location of the first ovulation (Marion and Gier, 1968). It is possible that through the prostaglandins it synthesizes, the involuting pregnant horn influences the ipsilateral ovary more than the contralateral ovary (Guilbaut et al., 1983). It has been suggested that progesterone could influence the concentrations of luteolytic and luteotropic factors (Pratt et al., 1982). It has been shown that progesterone pretreatment induces low and constant concentrations of PGFM, though not to a significant degree (Troxel and Kesler, 1984c).

An effect of progesterone on the hypothalamo-hypophyseal axis cannot be ruled out. It is well known that during the oestral cycle progesterone decreases the pulsatile secretion of LH (Ireland and Roche, 1982), because it has a negative feedback effect on its synthesis in the pituitary (Echterkamp and Hansel, 1973 ; Convey et al., 1977). This effect acts on higher nervous centers since progesterone modifies neither the $\mathrm{LH}$ content nor the number of $\mathrm{GnRH}$ receptors in the pituitary (Moss et al., 1981). This sensitivity of the pituitary to negative feedback exercised by progesterone increases during the postpartum period (Peters et al., 1983). During the postpartum period, the amplitude and the duration of the $\mathrm{LH}$ peak induced by $\mathrm{GnRH}$ injection is higher in animals pretreated with progesterone (Troxel et al., 1980; Troxel and Kesler, 1984c). Such an effect has not been confirmed by others (Williams et al., 1982 ; Azzazi et al., 1983). This observation should be taken in the context of the higher frequency of ovulation which occurs after progesterone treatment (Troxel and Kesler, 1984c). However, this did not occur after norgestomet treatment 40 days after calving (Troxel et al., 1980).

The opposing effects of progesterone on LH release are not necessarily contradictory. They may depend on the timing of the experiment in the period after calving. Thus the effect may be inhibitory during the first 3 weeks (Williams et al., 1982 ; Azzazi et al., 1983) and stimulatory later (Troxel et al., 1980 ; Troxel and Kesler, 1984c). The further away from calving it is given, the more likely it is for progesterone to have a favourable effect on $\mathrm{LH}$ release and the amount of progesterone synthesized by the resulting corpus luteum (Peters et al., 1983). This inhibitory effect is brought about by a decrease in the amount of $\mathrm{GnRH}$ released, by a decrease of the self-regulating (or self-priming) effect of $\mathrm{GnRH}$ (Kesner et al., 1982 ; Padmanabhan, 1982) or by oestradiol acting on the pituitary receptors of GnRH (Azzazi et al., 1983).

\subsection{Prolactin.}

During lactation, prolactin is released in response to a mammary stimulation (Tucker, 1971). In rats (Amenomori et al., 1970) and in women (Rolland et al., 
1975), the high blood prolactin concentrations are closely correlated with the gonadotropin synthesis inhibition. On the other hand, the high induced blood prolactin concentrations in rats (Fraser et al., 1982) or gestation or lactation (Reeves et al., 1982) is accompanied by a reduction of the number of pituitary $\mathrm{GnRH}$ receptors.

In the bovine, the anti-gonadotropic effect of prolactin cannot be accepted.

The prolactin plasma concentrations are the same in milked or suckled cows (Goodman et al., 1979 ; Smith et al., 1981), and in dairy cattle they are associated with increased milk yields (Akers et al., 1980). Prolactin release is not systematically connected with suckling (Gimenez et al., 1980 ; Convey et al., 1983). Moreover, anoestrus length was observed by some (Chang et al., 1981) but not others (Webb et al., 1980) to be closely correlated with plasma prolactin concentrations. Finally, the injection of prolactin (Forrest et al., 1980) or of bromocryptin (Williams and Ray, 1980), an inhibitor of prolactin release, influences neither the variations of $\mathrm{LH}$ or FSH concentrations nor the resumption of cyclic activity after calving delay at least in bovines. However, we cannot rule out an ovarian local effect of this hormone on the synthesis of progesterone (Mc Natty et al., 1976, 1977) and on follicular development (Tsai-Morris et al., 1983). The prolactin follicular concentration and the number of $\mathrm{LH}$ receptors are in fact significantly higher in weaned cows than in suckled cows (Walters et al., 1982a).

\subsection{Other hormonal factors.}

Experiments carried out with ovariectomized animals confirm that the ovary and its steroidal or peptide factors (Channing, 1978 ; Fraser, 1982 ; Sharpe, 1982) cannot play a determining part in the LH release mechanism after calving.

The presence of higher concentrations of glucocorticoids in the blood of suckled than non suckled cows before (Wagner and Oxenreider, 1972 ; Schallenberger et al., 1982) or after (Dunlap et al., 1981 ; Ellicott et al., 1981) a weaning period indicated that might play a role in $\mathrm{LH}$ release, the more so as they are likely to inhibit LH secretion in bovines (Wagner and Li, 1982). Recent work (Convey et al., 1983) has failed to confirm glucocorticoid release during suckling in non ovariectomized animals and again set the problem of the exact part played by those steroids in postpartum anoestrus in cows.

\section{Conclusions.}

Clinical and physiological studies lead to the conclusion that suckling has a major inhibitory effect on the resumption of regular sexual activity following parturition in the bovine species. Most specialists in bovine reproduction have tried to demonstrate and understand hormonal manifestations of the hypothalamo-hypophyso-ovarian axis during the postpartum weeks. They have stated the action mechanism of enhancing and determining factors and shown the importance of a pulsatile discharge of $\mathrm{LH}$ under $\mathrm{GnRH}$ control. So new approaches emerge. An increasing influence on follicular growth is attributed to the involuting uterus. Moreover, the isolation and purification of ovarian cybernins will allow a better understanding of the determinism of anoestrus. It would 
also be interesting to elucidate more precisely the effect of stresses such as parturition and suckling on neuromediators and endorphins at the level of the central nervous system level. Epidemiological research in bovine reproduction is now expanding. Because of its application in animal husbandry, it must define more accurately the respective roles of the different factors involved in anoestrus and clarify the economic implications of the therapeutic means already proposed to improve the fertility and fecundity of cattle.

Reçu en janvier 1986.

Accepté en septembre 1986

\section{Résumé. Régulation endocrinienne de l'ovaire au cours du postpartum dans l'espèce bovine.}

Dans l'espèce bovine, l'intervalle entre vêlages dépend notamment de la durée de l'ancestrus du postpartum. Plusieurs facteurs sont susceptibles d'influencer la physiologie de l'ovaire après la parturition: I'alimentation avant et après le vêlage, le niveau de production laitière, l'âge de l'animal, la nature du vêlage, la présence d'un taureau dans le troupeau, la saison et son photopériodisme mais surtout le caractère lactant ou allaitant de la vache. L'anoestrus est plus long chez la vache allaitante (30 à 110 jours) que chez la vache traite (20 à 70 jours).

Bien qu'encore incomplètes, les connaissances relatives à la physiologie de l'axe hypothalamo-hypophyso-ovarien au cours du postpartum ne cessent de progresser. Plusieurs faits apparaissent maintenant bien établis. La libération pulsatile de la $\mathrm{LH}$ et du $\mathrm{GnRH}$ ainsi que la sensibilité hypophysaire à la $\mathrm{GnRH}$ augmentent progressivement après le vêlage. Elles sont inhibées par l'allaitement qui agit plus sur la libération que sur la synthèse de la $\mathrm{LH}$ et du GnRH. La diminution de la synthèse d'œstrogènes par les follicules et la réduction de leur rétro-action positive sur l'axe hypothalamo-hypophysaire constituent la manifestation physiologique de cet effet inhibiteur. Après la parturition, la première phase lutéale est de plus courte durée et la synthèse de progestérone inférieure à celle observée au cours d'un cycle normal. II est possible qu'une lutéolyse prématurément induite par les prostaglandines d'origine utérine soit à l'origine de cette particularité. Les effets de la $\mathrm{FSH}$, de la prolactine et des corticoïdes, apparaissent nettement moins bien définis. De nouvelles voies d'approche se font jour. Nous citerons celles qui ont pour but de préciser le rôle de l'utérus en involution sur la croissance folliculaire ainsi que celles relatives aux cybernines ovariennes. L'étude du mécanisme d'action des facteurs de stress pourrait aussi revêtir des implications pratiques. Enfin, les recherches épidémiologiques en reproduction bovine permettront de cerner davantage l'effet respectif des différents facteurs impliqués dans l'ancestrus.

\section{References}

ACOSTA B., TARNAVSKY G. K., PLATT T. E., HAERNIK D. L., BROWN J. L., SCHOENEMANN H. M., REEVES J. J., 1983. Nursing enhances the negative effect of estrogen on LH release in the coiw. J. anim. Sci., 57, 1530-1536.

AMENOMORI Y. C., CHEN L., MEITES J., 1970. Serum prolactin levels in rats during different reproductive states. Endocrinology, 86, 506-510.

AKERS R. M., GOODMAN G. T., TUCKER H. A., 1980. Clearance and secretion rates of prolactin in dairy cattle in various physiological states. Proc. Soc. exp. Biol. Med., 168, 115-119.

APGAR J., ASPROS D., HIXON J. E., SAATMAN R. R., HANSEL W., 1975. Effect of restricted feed intake on the sensitivity of the bovine corpus luteum to LH in vitro. J. anim. Sci, 41, 1120-1123.

ARIJE G. R., WILTBANK J. N., HOPWOOD M. L., 1974. Hormone levels in pre- and post-parturient beef cows. J. anim. Sci, 39, 338-347.

AZZAZI F., KRAUSE G. F., GARVERICK H. A., 1983. Alteration of the GnRH-induced LH release by steroids in postpartum dairy cattle. J. anim. Sci., 57, 1251-1259. 
AZZAZI F., GARVERICK H. A., 1984. The effect of estradiol-17 $\beta$ and estrone administration on GnRH-induced LH release during the early postpartum in dairy cattle. Theriogenology, 21, 447-454.

BALL P. J. H., LAMMING G. E., 1983. Diagnosis of ovarian acyclicity in lactating dairy cows and evaluation of treatment with gonadotrophin-releasing hormone and progesterone-releasing intravaginal device. Br. vet. J., 139, 522-527.

BARRACLOUGH C. A., 1973. Sex steroid regulation of reproductive neuroendocrine processes, 29-56. In Handbook of physiology, Section 7, Vol. 2, Williams \& Wilkins.

BASTIDAS P., TROCONIZ J., VERDE O., SILVA O., 1984. Effect of restricted suckling on ovarian activity and uterine involution in brahman cows. Theriogenology, 21, 525-532.

BEAL W. E., SHORT R. E., STAIGMULLER R. B., BELLOWS R. A., KALTENBACH C. C., 1978. Influence of dietary energy intake on bovine pituitary and luteal function. J. anim. Sci., 46, 181-190.

BEAL W. E., MILVAE R. A., HANSEL W., 1980. Oestrous cycle length and plasma progesterone concentrations following administration of prostaglandin $\mathrm{F} 2 \alpha$ early in the bovine oestrous cycle. J. Reprod. Fert., 59, 393-396.

BECK L. V., BAY M., SMITH A. F., KING D., LONG R., 1978. Steroid-priming of luteinizing hormone response to luteinizing hormone-releasing hormone. J. Endocrinol., 77, 293-299.

BELLIN M. E., HINSHELWOOD M. M., HAUSER E. R., AX R. L., 1984. Influence of suckling and side of corpus luteum or pregnancy on folliculogenesis in postpartum cows. Biol. Reprod., 31, 849-855.

BELLOWS R. A., SHORT R. E., URICK J. J., PAHNISH D. F., 1974. Effects of early weaning on postpartum reproduction of the dam and growth of calves born as multiples or singles. $J$. anim. Sci., 39, 589-600.

BRANTMEIER S. A., BELLIN M. E., BUSHMEYER S. M., BOEHM S. K., KUBAJAK C. L., AX R. I., 1984. Follicular and luteal relationships in the bovine. Biol. Reprod., 30, Suppl. 1, 87.

BRITT J. H., KITTOK R. J., HARRISON D. S., 1974. Ovulation, estrus and endocrine response after GnRH in early postpartum cows. J. anim. Sci, 39, 915-919.

BULMAN D. C., LAMMING G. E., 1978. Milk progesterone levels in relation to conception, repeat breeding and factors influencing acyclicity in dairy cows. J. Reprod. Fert., 54, 447-458.

CALLAHAN C. J., ERB R. E., SURVE A. H., RANDEL R. D., 1971. Variables influencing ovarian cycles in postpartum dairy cows. J. anim. Sci, 33, 1053-1059.

CAMPBELL G. A., KURO M., MARSHALL S., MEITES J., 1977. Effects of starvation in rats on serum levels of follicle-stimulating hormone, luteinizing hormone, thyrotropin, growth hormone and prolactin: responses to LH-releasing hormone and thyrotropin-releasing hormone. Endocrinology, 100, 580-587.

CARRUTHERS T. D., KESNER J. S., CONVEY E. M., HAFS H. D., 1978. Hypothalamic GnRH and pituitary function in suckled and non suckled Holstein cows. J. anim. Sci., 47 (Suppl. 1), 349.

CARRUTHERS T. D., HAFS H. D., 1980. Suckling and four times daily milking. Influence on ovulation, estrus and serum luteinizing hormone, glucocorticoids and prolactin in postpartum dairy cows. J. anim. Sci, 50, 919-925.

CARRUTHERS T. D., CONVEY E. M., KESNER J. S., HAFS H. D., CHENG K. W., 1980. The hypothalamic-pituitary gonadotropic axis of suckled and nonsuckled dairy cows postpartum. J. anim. Sci., 51, 949-957.

CARSTAIRS J. A., MORROW D. A., EMERY R. S., 1980. Postpartum reproductive function of dairy cows as influenced by energy and phosphorus status. J. anim. Sci, 51, 1122-1130.

CARTER M. L., DIERSCHKE J., RUTLEDGE J. J., HAUSER E. R., 1980. Effect of gonadotropinreleasing hormone and calf removal on ovarian pituitary function and reproductive performance in postpartum beef cows. J. anim. Sci., 51, 903-910.

CASIDA L. E., GRAVES W. E., HAUSER E. R., LAUDERDALE J. W., REISEN J. W., DAIDUDDIN S., TYLER W. J., 1968. Studies in the postpartum cow. Res. Bull. agric. exp. Stn. Univ. Wisc., $\mathrm{n}^{\circ} 270$.

CHANG C. H., GIMENEZ T., HERNRICKS D. M., 1981. Modulation of reproductive hormones by suckling and exogenous gonadal hormones in young beef cows postpartum. J. Reprod. Fert., 63. 31-38. 
CHANNING C. P., 1978. Follicular non steroidal regulators. Adv. exp. Med. Biol., $112,327$.

CHANNING C. P., ANDERSON L. D., HOOVER D. J., GAGLIANO P., HODGEN G., 1981. Inhibitory effects of porcine follicular fluid on monkey serum FSH levels and follicular maturation. Biol. Reprod., 25, 885-903.

CLAPP H., 1937. A factor in breeding efficiency of dairy cattle. Proc. amer. Soc. anim. Prod., 37, 259-265.

CONVEY E. M., BECK T. W., NEITZEL R. R., BOSTWICK E. F., HAFS H. D., 1977. Negative feedback control of bovine serum luteinizing hormone (LH) concentration from completion of the pre-ovulatory LH surge until resumption of luteal function. J. anim. Sci., 45, 792-796.

CONVEY E. M., TUCKER H. A., SHORT R. E., 1983. Acute effect of suckling on gonadotropin, prolactin and glucocorticoid concentrations in serum of intact and ovariectomised beef cows. Theriogenology, 20, 661-674.

CORAH L. R., QUEALY A. P., DUNN T. G., KALTENBACH C. C., 1974 . Prepartum and postpartum levels of progesterone and estradiol in beef heifers fed two levels of energy. J. anim. Sci., 39, 380-385.

CORAH L. R., DUNN T. G., KALTENBACH C. C., 1975. Influence of prepartum nutrition on the reproductive performance of beef females and the performance of their progeny. J. anim. Sci., 41, 819-824.

CROWDER M. E., GILlES P. A., TAMANINI C., MOSS G. E., NETT T. M., 1982. Pituitary content of gonadotropins and $\mathrm{GnRH}$ receptors in pregnant, postpartum and steroid-treated ovariectomised ewes. J. anim. Sci., 54, 1235-1242.

CUMMINS L. J., CUMMING I. A., KNIGHT M. A., LAWSON R. A. S., 1975. LH release by cows in response to GnRH during the postpartum period. J. Reprod. Fert., 43, 397-398.

DONALDSON L. E., BASSETT J. M., THORBURN J. D., 1970. Peripheral plasma progesterone concentration of cows during puberty, oestrous cycle, pregnancy and lactation and the effects of undernutrition or exogenous oxytocin on progesterone concentration. $J$. Endocrinol., 48, 599-614.

DUBY R. T., BROWNING T., CAREY D., BLOCK D. L., 1985. Progesterone synthesis and histology of postpartum bovine corpora lutea. Theriogenology, 23, 619-630.

DUFFOUR J. J., 1975. Influence of post weaning growth rate on puberty and ovarian activity in heifers. Can. J. anim. Sci., 55, 93-100.

DUNLAP S. E., KISER T. E., RAMPACEK G. B., KRAELING R. R., THOMPSON F. N., 1981. Effect of suckling on cortisol, progesterone and luteinizing hormone in postpartum beef cows. TheriogenologV, 16, 185-193.

DUNN T. G., INGALLS J. E., ZIMMERMAN D. R., WILTBANK J. N., 1969. Reproductive performance of 2-year old Hereford and Angus heifers as influenced by pre and post-calving energy intake. J. anim. Sci., 29, 719-726.

DUNN T. G., RONE J., KALTENBACH C. C., VANDER WALT L. A., RILEY M. L., AKBAR A. M., 1974. Hormone changes during underfeeding of beef cows. J. anim. Sci., 39, 206 (Abstr.).

DUNN T. G., KALTENBACH C. C., 1980. Nutrition and the postpartum interval of the ewe, sow and cow. J. anim. Sci., 51, suppl. 2, 29-39.

DUNN R. T., SMITH M. F., GARVERICK H. A., FOLEY C. W., 1985. Effects of 72 hr calf removal and/or gonadotropin-releasing hormone on luteinizing hormone release and ovarian activity in postpartum beef cows. Theriogenology, 23, 767-776.

ECHTERKAMP S. E., HANSEL W., 1973. Concurrent changes in bovine plasma hormone levels prior to and during the first postpartum estrus cycle. J. anim. Sci., 37, 1362-1370.

ECHTERKAMP S. E., FERRELL C. L., RONE J. D., 1982. Influence of pre and postpartum nutrition on LH secretion in the suckled postpartum beef heifers. Theriogenology, 18, 283-295.

EDGERTON L. A., 1980. Effect of lactation upon the interval postpartum. J. anim. Sci., suppl. 2 , 51, 29-39.

EDGERTON L. A., HAFS H. D., 1973. Serum luteinizing hormone, prolactin, glucocorticoid and progestin in dairy cows from calving to gestation. J. dairy Sci., 56, 451-458.

EDQVIST L. A., KINDAHL H., STABENFELDT G. H., 1978. Release of prostaglandin F2 $\alpha$ during the bovine peripartal period. Prostaglandins, 16, 111-119.

EDWARDS S., 1985. The effects of short-term calf removal on pulsatile LH secretion in the postpartum beef cow. Theriogenology, 23, 777-785. 
ELLICOTT A. R., HENRICKS D. M., GIMENEZ T., KISER T. E., 1981. Suckling induced cortisol in young beef cows. Theriogenology, 16, 469-475.

ERB R. B., HINZE P. M., GILDOW E. M., MORRISON R. A., 1958. Retained fetal membranes. The effect on prolificacy of dairy cattle. J.A.V.M.A., 133, 489-496.

ETHERINGTON W. G., BOSU W. T. K., MARTIN S. W., COTE J. F., DOIG P. A., LESLIE K. E., 1984. Reproductive performance in dairy cows following postpartum treatment with gonadotrophin-releasing hormone and or prostaglandin. A field trial. J. comp. Med, 48, 245-250.

FERNANDES L. C., THATCHER W. W., WILCOX C. J., CAL E. P., 1978. LH release in response to GnRH during the postpartum period of dairy cows. J. anim. Sci., 46, 443-448.

FLOOD P. F., MANNS J. G., HUMPHREY W. D., MAPLETOFT R. J., 1979. The first corpus luteum of the postpartum beef cows. Proc. Soc. Study Fertil, 30.

FONSECA F. A., BRITT J. H., KOSUGIYAMA M., RITCHIE H. D., DILLARD E. U., 1980. Ovulation, ovarian function and reproductive performance after treatments with $\mathrm{GnRH}$ in postpartum suckled cows. Theriogenology, 13, 171-181.

FORREST D. W., FLEEGER J. L., LONG C. R., SORENSON A. M., HARMS R. G., 1980 . Effect of exogenous prolactin an peripheral luteinizing hormone levels in ovariectomised cows. Biol. Reprod., 22, 197-201.

FOSTER J. P., LAMMING G. E., PETERS A. R., 1980. Short-term relationships between plasma LH, FSH and progesterone concentrations in postpartum dairy cows and the effect of GNRH injection. J. Reprod. Fert., 59, 321-327.

FRASER H. M., 1982. Antifertility effects of GNRH. J. Reprod. Fert., 64, 503-515.

FRASER H. M., POPKIN R. M., Mc NEILLY A. S., SHARPE R. M., 1982. Changes in pituitary LHRH receptor levels in situations of increased or decreased gonadotropin secretion in the male rat. Mol. cell. Endocrinol., 28, 321-331.

GAUTHIER D., THIMONIER H., 1982. Variations saisonnières de la cyclicité chez la génisse créole, influence de la croissance, de l'âge et de l'émotivité. Reprod. Nutr. Dévelop., 22, 681-688.

GAUTHIER D., BLANC M. R., PETIT M., PELLETIER J., 1982. FSH and LH variations in beef cows during the postpartum period. Reprod. Nutr. Dévelop., 22, 283-290.

GAUTHIER D., TEROUI M., MAULÉON P., 1983. Influence of nutrition on prepartum plasma levels of progesterone and total oestrogens and postpartum plasma levels of luteinizing hormone and follicle-stimulating hormone in suckling cows. Anim. Prod., 37, 89-96.

GAUTHIER D., MAULÉON P., 1983. Influence of dietary intake and weight variation on LH release after a gonadotropin-releasing hormone (GNRH) injection during the postpartum period of the nursing cow. Reprod. Nutr. Dévelop., 23, 829-835.

GERM PLASM EVALUATION PROGRAM, 1975. Progress report, 2, US Meat Animal Research Center.

GIMENEZ T., HENRICKS D. M., ELLICOTT A. R., CHANG C. H., RONE J. D., GRIMES L. W., 1980. Prolactin and luteinizing hormone (LH) release throughout the postpartum period in the suckled first calf beef cow. Theriogenology, 14, 135-149.

GOMBE S., HANSEL W., 1973. Plasma luteinizing hormone (LH) and progesterone levels in heifers on restricted energy intakes. J. anim. Sci, 37, 728-733.

GOODMAN G. T., TUCKER H. A., CONVEY E. M., 1979. Presence of the calf affects secretion of prolactin in cows. Proc. Soc. exp. Biol. Med., 169, 421-424.

GRAVES W. E., LAUDERDALE J. W., HAUSER E. R., CASIDA L. E., 1968. Relation of postpartum interval to pituitary gonadotropins, ovarian follicular development and fertility in beef cows. Univ. Wisconsin Res. Bull., 270, 23-26.

GUILBAUT L. A., THATCHER W. W., DROST M., HOPKINS S., FOSTER D. B., 1981. A uterine prolapse and hysterectomy model to characterize PGFM dynamics in the early postpartum period. J. anim. Sci, 53, Suppl. 1, 323.

GUILBAUt L. A., THATCHER W. W., HAIBEL G., DROST M., WILCOX C. J., 1983. Hormonal uterine and ovarian response to physiological infusions of PGF2 $\alpha$ in postpartum cows with suppressed endogenous production of prostaglandins. J. anim. Sci., 57, Suppl. 1, 503.

GUILBAUT L. A., THATCHER W. W., FOSTER D. B., CATON D., 1984a. Relationship of 15-keto13,14-dihydro-prostaglandin $F 2 \alpha$ concentrations in peripheral plasma with local uterine production of $\mathrm{F}$ series prostaglandins and changes in uterine blood flow during the early postpartum period in cattle. Biol. Reprod., 31, 870-878. 
GUILBAUT L. A., THATCHER W. W., DROST M., HOPKINS S. M., 1984b. Source of F series prostaglandins during the early postpartum period in cattle. Biol. Reprod., 31, 879-887.

HANSEN P. J., BAIK D. H., RUTLEDGE J. J., HAUSER E. R., 1982. Genotype $\times$ environmental interactions on reproductive traits of bovine females. 2. Postpartum reproduction as influenced by genotype, dietary regimen, level of milk production and parity. $J$. anim. Sci., 55, 1458-1472.

HANSEN P. J., HAUSER E. R., 1983. Genotype $\times$ environmental interactions on reproductive traits of bovine females. 3. Seasonnal variation in postpartum reproduction as influenced by genotype, suckling and dietary regimen. J. anim. Sci., 56, 1362-1369.

HANSEN P. J., HAUSER E. R., 1984. Photoperiodic alteration of postpartum reproductive function in suckled cows. Theriogenology, 22, 1-14.

HARESIGN W., 1981. The influence of nutrition on the reproduction in the ewe. 2. Effects of undernutrition on pituitary responsiveness to luteinizing hormone-releasing hormone stimulation. Anim. Prod., 32, 257-260.

HILL J. R., LAMOND D. R., HENRICKS D. M., DICKEY J. F., NISWENDER G. D., 1970. The effects of under-nutrition on ovarian function and fertility in beef heifers. Biol. Reprod., 2, 7884.

HOBSON W. C., HANSEL W., 1972. Plasma LH levels after ovariectomy, corpus luteum removal and estradiol administration. Endocrinology, 91, 185-190.

HOLNESS D. H., HOPLEY J. D. H., HALE D. H., 1978. The effects of plane of nutrition live weight, temporary weaning and breed on the occurrence of oestrus during the postpartum period. Anim. Prod., 26, 47-54.

HSUEH A. J. W., ERICKSON G. F., YEN S. S. C., 1979. The sensitizing effect of estrogens and catecholestrogens on cultured pituitary cells to luteinizing hormone-releasing hormone: its antagonism by progestins. Endocrinology, 104, 807-813.

HUMPHREY W. D., KORITNIK D. R., KALTENBACH C. C., DUNN T. B., NISWENDER G. D., 1976. Progesterone and $\mathrm{LH}$ in postpartum suckled beef cows. J. anim. Sci., 43, 290 (Abstr.).

HUMPHREY W. D., KALTENBACH C. C., DUNN T. G., KORITNIK D. R., NISWENDER G. D., 1983. Characterization of hormonal patterns in the beef cow during postpartum anestrus. J. anim. Sci., 56, 445-453.

IRELAND J. J., ROCHE J. F., 1982. Effect of progesterone on basal LH and episodic LH and FSH secretion in heifers. J. Reprod. Fert., 64, 295-302.

IRVIN H. J., ZAIED A. A., DAY B. N., GARVERICK H. A., 1981. GnRH-induced release in suckled beef cows. 1 . The effects of days postpartum and estradiol-17 $\beta$ concentrations on the release of $\mathrm{LH}$ following administration of $\mathrm{GnRH}$. Theriogenology, 15, 443-448.

JAINUDEEN M. R., BONGSO T. A., TAN T. S., 1982-1983. Postpartum ovarian activity and uterine involution in the suckled swamp buffalo (Bubalis bubalis). Anim. Reprod. Sci., 5, 181-190.

JORDAN E. R., SWANSON L. V., 1979. Serum progesterone and luteinizing hormone in dairy cattle fed varying levels of crude protein. J. anim. Sci., 48, 1154-1158.

KAISER A. G., 1975. Rearing dairy beef calves by multiple suckling. 1. Effects of liveweight change, onset of oestrus and post-weaning milk production. Austr. J. exp. Agric. Anim. Husb., 15. $17-24$

KASER M. L., MURRAY R. D., DOBSON H., 1984. Plasma hormone changes in cows during induced or spontaneous calvings and the early postpartum period. Vet. Rec., 115, 378-382.

KESLER D. J., GARVERICK H. A., YOUNQUIST R. S., ELMORE R. G., BIERSCHWAL C. J., 1977. Effect of days postpartum and endogenous reproductive hormones on $\mathrm{GnRH}$-induced $\mathrm{LH}$ release in dairy cows. J. anim. Sci, 46, 797-803.

KESLER D. J., GARVERICK H. A., BIERSCHWAL C. J., ELMORE R. G., YOUNGQUIST R. S., 1979. Reproductive hormones associated with normal and abnormal changes in ovarian follicles in postpartum dairy cows. J. Dairy Sci., 62, 1290-1296.

KESLER D. J., TROXEL T. R., HIXON D. L., 1980. Effect of days postpartum and exogenous GnRH on reproductive hormone and ovarian changes in postpartum-suckled beef cows. Theriogenology, 13, 287-298.

KESLER D. J., WESTON P. G., PIMENTAL C. A., TROXEL T. R., VINCENT D. L., HIXON J. E., 1981. Diminution of the in vitro response to luteinizing hormone by corpora induced by 
gonadotropin-releasing hormone treatment of postpartum suckled beef cows. J. anim. Sci, 53, 749-754.

KESNER J. S., CONVEY E. M., ANDERSON C. R., 1981. Evidence that estradiol induces the preovulatory LH surge in cattle by increasing pituitary sensivity to $\mathrm{LH}-\mathrm{RH}$ and then increasing $\mathrm{LH}-\mathrm{RH}$ release. Endocrinology, 108, 1386-1391.

KESNER J. S., RIEBOLD T. W., CONVEY E. M., 1982. Effect of dosage and frequency of injection of luteinizing hormone-releasing hormone on release of luteinizing hormone and folliclestimulating hormone in estradiol-treated heifers. J. anim. Sci., 54, 1023-1029.

KING G. J., Mc LEOD G. K., 1983-1984. Reproductive function in beef cows calving in the spring or fall. Anim. Reprod. Sci., 6, 255-266.

LAMMING G. E., WATHES D. C., PETERS A. R., 1981. Endocrine patterns of the postpartum cow. J. Reprod. Fert., Suppl. 30, 155-170.

LAMOND D. R., 1970. The influence of undernutrition on reproduction in the cow. Anim. Breed. Abstr., 38, 372.

LASTER D. B., GLIMP H. A., CUNDIFF L. V., GREGORY K. E., 1973. Effects of early weaning on postpartum reproduction of cows. J. anim. Sci, 36, 734-740.

LAVOIE V., HAN D. K., FOSTER D. B., MODDY E. L., 1981. Suckling effect on estrus and blood progesterone in postpartum beef cows. J. anim. Sci., 52, 802-812.

LEWIS G. S., THATCHER W. W., BILSS E. L., DROST M., COLLIER R. J., 1984 . Effects of heat stress during pregnancy on postpartum reproductive changes in Holstein cows. J. anim. Sci., 58, 174-186.

LINDELL J. O., KINDAHL H., JANSSON L., EDQVIST L. E., 1982. Postpartum release of prostaglandin F2 $\alpha$ and uterine involution in the cow. Theriogenology, 17, 237-245.

LISHMAN A. W., ALLISON S. M. J., FOGWELL R. L., BUTCHER R. L., INSKEEP E. K., 1979. Follicular development and function of induced corpora lutea in underfed postpartum anestrous beef cows. J. anim. Sci., 48, 867-875.

Mc NATTY K. P., NEAL P., BAKER T. G., 1976. Effect of prolactin on the production of progesterone by mouse ovaries in vitro. J. Reprod. Fert., 47, 155-156.

MC NATTY K. P., Mc NEILLY A. S., SAWERS R. S., 1977. Prolactin and progesterone secretion by human granulosa cells in vitro, 109. In CROSIGNANI P. G., ROBYN C., Proceed. Serono Symp., Prolactin and reproduction, Vol. 11, Acad. Press, New York.

Mc NATTY K. P., hUDSON N., GIBB M., HENDERSON K. M., LUN S., HEATH D., MONT. GOMERY G. W., 1984. Seasonal differences in ovarian activity in cows. J. Endocr., 102, 189-198.

MADEJ A., KINDAHL H., WOYNO W., EDQVIST L. E., STUPNICKI R., 1984. Blood levels of 15-keto-13,14-dihydro prostaglandin $\mathrm{F} 2 \alpha$ during the postpartum period in primiparous cows. Theriogenology, 21, 279-287.

MANNS J. G., RICHARDSON G., 1976. Induction of cyclic activity in the early postpartum dairy cows. Can. J. anim. Sci., 56, 467-473.

MANNS J. G., HUMPHREY W. D., FLOOD P. F., MAPLETOFT R. J., RAWLINGS N., CHENG K. W., 1983. Endocrine profiles and functionnal characteristics of corpora lutea following onset of postpartum ovarian activity in beef cows. Can. J. anim. Sci., 63, 331-347.

MARION G. B., GIER H. T., 1968. Factors affecting bovine ovarian activity after parturition. J. anim. Sci, 27, 1621-1626.

MATTON P., ADELAKOON V., COUTURE Y., DUFOUR J., 1981. Growth and replacement of the bovine ovarian follicles during the estrous cycle. J. anim. Sci., 52, 813-820.

MONTGOMERY G. W., DAVIS G. H., HURRELL G. A., 1980 . Interval from calving to first oestrus in autumn and spring calving herds in the same locality. Proc. N. Z. Soc. anim. Prod., 40, 280-284.

MONTGOMERY G. W., 1982. Influence of suckling frequency and bromocryptine treatment on the resumption of ovarian cycles in postpartum beef cattle. Theriogenology, 17, 551-563.

MONTGOMERY G. W., SCOTT I. C., HUDSON N., 1985. An interaction between season of calving and nutrition on the resumption of ovarian cycles in postpartum beef cattle. J. Reprod. Fert., 73, 45-50.

MORROW D. A., ROBERTS S. J., Mc ENTEE L., 1969. Review of postpartum ovarian activity and involution of the uterus and cervix in cattle. Cornell Vet., 59, 134-145. 
MOSS G. E., CROWDER M. E., NETT T. M., 1981. GnRH-receptor interaction. 6. Effect of progesterone and estradiol on hypophyseal receptors for $\mathrm{GnRH}$, and serum and hypophyseal concentrations of gonadotropins in ovariectomised ewes. Biol. Reprod., 25, 938-944.

MOSS G. E., PARFET J. R., DIEKMAN M. A., LEMENAGER R. P., HENDRIX K. S., 1982. Pituitary luteinizing hormone, follicle-stimulating hormone, serum progesterone and hypothalamic gonadotropin-releasing hormone in beef cows in varied body conditions. J. anim. Sci., $\mathbf{5 5}$, suppl. 1, 374.

MUNRO C. J., MC NATTY K. P., RENSHAW L., 1980. Circa-annual rhythms of prolactin secretion in ewes and the effect of pinealectomy. J. endocr., 87, 83-89.

NANCARROW C., RADFORD R. J., SCARAMUZZI R. J., POST T. B., 1977. Responses to injected estrogen in suckled cows. Theriogenology, 8, 192.

ODDE K. G., WARD H. S., KIRACOFE G. H., Mc KEE R. M., KITTOCK R. J., 1980 . Short estrous cycles and associated serum progesterone levels in beef cows. Theriogenology, 14, 105-112.

OXENREIDER S. L., 1968. Effects of suckling and ovarian function on postpartum reproductive activity in beef cows. Amer. J. vet. Res., 29, 2099-2102.

PADMANABHAN V., LEUNG K., CONVEY E. M., 1982. Ovarian steroids modulate self-priming effect of luteinizing hormone-releasing hormone on bovine pituitary cells in vitro. Endocrinology, 110, 717-721.

PETERS A. R., LAMMING G. E., FISHER M. W., 1981. A comparison of plasma LH concentrations in milked and suckling postpartum cows. J. Reprod. Fert., 62, 567-573.

PETERS A. R., RILEY G. M., 1982. Milk progesterone profiles and factors affecting postpartum ovarian activity in beef cows. Anim. Prod., 34, 145-153.

PETERS A. R., HEWITT D. S., LAMMING G. E., 1983. The effect of exogenous progesterone on plasma LH and milk progesterone concentrations in multiple suckling postpartum cows. Anim. Reprod. Sci., 6, 103-110.

PETERS A. R., 1984. Effect of exogenous oestradiol-17 $\beta$ an gonadotrophin secretion in postpartum beef cows. J. Reprod. Fert., 72, 473-478.

PETERS A. R., LAMMING G. E., 1984. Reproductive activity of the cow in the postpartum period. 2. Endocrine patterns and induction of ovulation. Br. vet. J., 140, 269-280.

PIRCHNER F., ZWIAUER D., BUTLER I., CLAUS R., KARG H., 1983. Environmental and genetic influences on postpartum milk progesterone profiles of cows. Z. Tierzuchtg. Zuchtgsbiol., 100, 304-315.

POPE G. S., 1982. Oestrogens and progesterone in plasma and milk of postpartum dairy cattle, 248-272. In KARG E., SCHALLENBERGER E., Factors influencing fertility in the postpartum dairy cow, Martinus Nijhoff, The Hague,

PRATT B. R., BERNARDINELLI J. G., STEVENS L. P., INSKEEP E. K., 1982. Induced corpora lutea in postpartum beef cows. 1. Comparison of gonadotropin-releasing hormone and human chorionic gonadotropin and effects of progestagen and estrogen. J. anim. Sci., 54, 822-829.

RADFORD H. M., NANCARROW C. D., MATTNER P. E., 1978. Ovarian function in suckling and non suckling beef cows postpartum. J. Reprod. Fert., 54, 49-56.

RAMIREZ-GODINEZ J. A., KIRACOFE G. H., Mc KEE R. M., SCHALLES R. R., KITTOCK R. J., 1981. Reducing the incidence of short estrous cycles in beef cows with norgestomet. Theriogenology, 15, 613-623.

RAMIREZ-GODINEZ J. A., KIRACOFE G. H., SCHALLES R. R., NISWENDER G. D., 1982a. Endocrine patterns in the postpartum beef cow associated with weaning : a comparison of the short and subsequent normal cycles. J. anim. Sci., 55, 153-158.

RAMIREZ-GODINEZ J. A., KIRACOFE G. H., CORNAHAN D. L., SPIRE M. F., BEEMAN K. B., STEVENSON J. S., SCHALLIS R. R., 1982b. Evidence for ovulation and fertilisation in beef cows with short estrous cycles. Theriogenology, 17, 409-414.

RANDEL R. D., ERB R. E., 1971. Reproductive steroids in the bovine. 6. Changes and interrelationships from 0 to 260 days of pregnancy. J. anim. Sci. 33, 115-123.

RANDEL R. D., WALKER A., 1976. Once daily suckling effects on cow-calf performance. J. anim. Sci., 43, 301.

RANDEL R. D., 1981. Effect of once daily suckling on postpartum interval and cow-calf performance of first calf Brahman $\times$ Hereford heifers. J. anim. Sci., 53, 755-757. 
RAWLINGS N. C., WEIS L., TODD B., MANNS J., HYLAND J. H., 1980. Some endocrine changes associated with the postpartum period of the suckling beef cow. J. Reprod. Fert., 60, 301308.

REEVES J. J., TARNAVSKY G. K., PLATT T., 1982. Pituitary and ovarian luteinizing hormone releasing hormone receptors during the oestrous cycle, pregnancy and lactation in the rat. Biol. Reprod., 27, 316-319.

RICHARDS J. S., IRELAND J. J., RAO M. C., BERNATH G. A., MIDGLEY A. R., REICHERT L. E., 1976. Ovarian follicular development in the rat: hormone receptor regulation by estradiol, follicle-stimulating hormone and luteinizing hormone. Endocrinologv, 99, 1562-1570.

RICHARDSON G. F., ARCHBALD L. F., GALTON D. M., GODKE R. A., 1983. Effects of gonadotropin-releasing hormone and prostaglandin $\mathrm{F} 2 \alpha$ on reproduction in postpartum dairy cows. Theriogenology, 19, 763-770.

ROBERTS J. S., BARCIKOWSKI B., WILSON L., SKARNES R. C., MC CRACKEN J. A., 1975. Hormonal and related factors affecting the release of PGF2 $\alpha$ from the uterus. J. Steroid Biochem., 6, 1091.

ROLLAND R., LEQUIN R. M., SCHELLEKENS L. A., DE JONG F. H., 1975. Role of prolactin in restoration of ovarian function during the early postpartum period in the human female. 1. Study during physiological lactation. Clin. Endocr., 4, 15-25.

RUTTER L. M., RANDEL R. D., 1984. Postpartum nutrient intake and body condition. Effect on pituitary function and onset of estrus in beef cattle. J. anim. Sci, 58, 265-274.

SAIDUDDIN S., RIESEN J. W., GRAVES W. E., TYLER W. J., CASIDA L. E., 1968. Relation of postpartum interval to pituitary gonadotropins, ovarian follicular development and fertility in dairy cows. Univ. Wisconsin Res. Bull., 270, 15-22.

SAIDUDDIN S., ZASSENHAUS H. P., 1978. Effect of testosterone and progesterone on the estradiol receptor in the immature rat ovary. Endocrinology, 102, 1069-1076.

SCHALLENBERGER E., SCHAMS E. D., ZOTTMEJER K., 1978. Response of lutropin (LH) and follitropin (FSH) to the administration of gonadoliberin $(\mathrm{GnRH})$ in pregnant and postpartum cattle including experiments with prolactin suppression. Theriogenologv, 10, 35-54.

SCHALLENBERGER E., PETERSON A. J., 1982. Effect of ovariectomy on tonic gonadotrophin secretion in cyclic and postpartum dairy cows. J. Reprod. Fert., 64, 47-52.

SCHALLENBERGER E., OERTERER U., HUTTSER G., 1982. Neuroendocrine regulation of postpartum function, 123-147. In KARG H., SCHALLENBERGER E., Factors influencing fertility in the postpartum cow, Martinus Nijhoff, The Hague.

SCHAMS D., HOFER F., HOFFMAN B., ENDER M. L., KARG H., 1973. Effects of synthetic LH-RH treatment on bovine ovarian function during oestrous cycle and postpartum period. Acta endocrinol., Suppl. 177, 296.

SCHAMS D., SCHALLENBERGER E., MENZER C., STANGL J., ZOTTMEIER K., HOFFMAN B., KARG H., 1978. Profiles of LH, FSH and progesterone in postpartum dairy cows and their relationship to the commencement of cyclic functions. Theriogenology, 10, 453-468.

SHARPE R. M., 1982. Cellular aspects of the inhibitory actions of LHRH on the ovary and testis. J. Reprod. Fert., 64, 517-527.

SHEFFEL C. E., PRATT B. R., INSKEEP E. K., 1980. Effect of progestogen and PMSG or FSH on induced corpora lutea in cattle. J. anim. Sci., 51, Suppl. 1, 328.

SHEFFEL C. E., PRATT B. R., INSKEEP E. K., 1982. Induced corpora lutea in the postpartum beef cows. 2. Effects of treatment with progesterone and gonadotropins. J. anim. Sci., 54, 830836.

SHORT R. V., 1958. Progesterone in blood. 2. Progesterone in peripheral blood of pregnant cows. J. Endocrinol., 16, 426-428.

SHORT R. E., BELLOWS R. A., MOODY E. L., HOWLAND B. E., 1972. Effects of suckling and mastectomy on bovine postpartum reproduction. J. anim. Sci., 34, 70-74.

SHORT R. E., RANDEL R. D., STAIGMULLER R. B., BELLOWS R. A., 1979. Factors affecting estrogen-induced LH release in the cow. Biol. Reprod, 21, 683-689.

SMITH L. E., VINCENT C. K., 1972. Effects of early weaning and exogenous hormone treatment on bovine postpartum reproduction. J. anim. Sci., 35, 1228-1232. 
SMITH V. G., EDGERTON L. A., HAFS H. D., CONVEY E. M., 1973. Bovine serum estrogens, progestin and glucocorticoids during late pregnancy, parturition and early lactation. J. anim. Sci., 36, 391-396.

SMITH M. F., WALTERS D. L., HARMS P. G., WILTBANK J. N., 1977. LH levels after steroids and/or $48 \mathrm{hr}$ calf removal in anestrous cows. J. anim. Sci, 45, Suppl, 1, 209.

SMITH M. F., BURRELL W. C., SHIP L. D., SPROTT L. R., SONGSTER W. N., WILTBANK J. N., 1979. Hormone treatments and use of calf removal in postpartum beef cows. J. anim. Sci., 48, 1285-1294.

SMITH J. F., PAYNE E., TERVIT H. R., Mc GOWAN L. T., FAIRCLOUgh R., KILGOUR R., GOOLD P. G., 1981. The effect of suckling upon the endocrine changes associated with anoestrous in identical twin dairy cows. J. Reprod. Fert., suppl. 30, 241.

SMITH M. F., LIHMAN A. W., LEWIS G. S., HARMS P. G., ELLERSIECK M. R., INSKEEP E. K., WILTBANK J. N., AMOSS M. S., 1983. Pituitary and ovarian responses to gonadotropinreleasing hormones, calf removal and progestagen in anestrous beef cow. J. anim. Sci., 57 , 418-424.

SPITZER J. C., NISWENDER G. D., SEIDEL G. E., WILTBANK J. N., 1975. Fertilization and endocrinology in underfed heifers. J. anim. Sci, 41, 380 (Abstr.).

SPITZER J. C., NISWENDER G. D., SEIDEL G. E., WILTBANK J. N., 1978. Fertilization and blood levels of progesterone and LH in beef heifers on a restricted diet. J. anim. Sci., 46, 1071-1077.

STELLFLUG J. N., HAHN D. K., RANDEL R. D., MOODY E. L., 1978 . Plasma oestrogen in the periparturient cow. Theriogenology, 10, 269-273.

STEVENSON J. S., BRITT J. H., 1979. Relationships among luteinizing hormone, estradiol, progesterone, glucocorticoids, milk yield, body weight and postpartum ovarian activity in Holstein cows. J. anim. Sci., 47, 570-577.

STEVENSON J. S., SPIRE M. F., BRITT J. H., 1983. Influence of the ovary on estradiol-induced luteinizing hormone release in postpartum milked and suckled Holstein cows. J. anim. Sci., 57, 692-698.

TANG L. K. L., 1977. Differential feedback by estradiol-17 $\beta$ on LH production and LH-RH. Endocrinol. Res. Comm., 364, 217.

TERQUI M., CHUPIN D., GAUTHIER D., PEREZ N., PÉLOT J., MAULÉON P., 1982. Influence of management and nutrition on post-partum endocrine function and ovarian activity in cows, 384-408. In KARG E., SCHALLENBERGER E., Factors influencing fertility in the postpartum cow. Martinus Nijhoff, The Hague, Netherlands.

TERVIT H. R., SMITH J. F., KALTENBACH C. C., 1977. Postpartum anoestrus in beef cattle : a review. Proc. N. Z. Soc. anim. Prod., 37, 109-119.

THATCHER W. W., WILCOX C. J., COLLIER R. J., ELEY D. S., HEAD H. H., 1980. Bovine conceptus-maternal interactions during the pre and postpartum periods. J. Dairy Sci, 63, 15301540.

THIBAULT C., COUROT M., MARTINET L., MAULÉON P., DU MESNIL DU BUISSON F., ORTAVANT R., PELLETIER J., SIGNORET J. P., 1966. Regulation of breeding season and estrous cycles by light and external stimuli in some animals. J. anim. Sci., 25, 119-139.

TRIBBLE R. L., SORENSEN A. M., WOODWARD T. L., CONNOR J. J., BEVERLEY J. R., FLEEGER J. L., 1973. Serum progestins and luteinizing hormone levels in non-suckled primiparous heifers. Nature (Lond), 246, 494-495.

TROXEL T. R., KESLER D. J., NOBLE R. C., CARLIN S. E., 1980. Ovulation and reproductive hormones following steroid pretreatment, calf removal and $\mathrm{GnRH}$ in postpartum beef cows. J. anim. Sci, 51, 652-659.

TROXEL T. R., CMARIK G. F., OTT R. S., LOCK T. F., KESLER D. J., 1983. The effect of method of $\mathrm{GnRH}$ administration and short-term calf removal on ovarian function and reproductive performance in postpartum suckled beef cows administered $\mathrm{PGF}_{2 \alpha}$ for estrous synchronisation. Theriogenology, 20, 417-433.

TROXEL T. R., KESLER D. J., 1984a. The ability of indomethacin to alter prostaglandin metabolite concentrations and to enhance function of induced corpora lutea in postpartum suckled beef cows. J. anim. Sci., 59, 177-181. 
TROXEL T. R., OPSOMER M. J., KESLER D. J., 1984b. The effect of days postpartum, indomethacin and oxytocin on prostaglandin metabolite concentrations in postpartum suckled beef cows. Theriogenology, 22, 187-196.

TROXEL T. R., KESLER D. J., 1984c. The effect of progestin and GnRH treatments on ovarian function and reproductive hormone secretions of anestrous postpartum suckled beef cows. Theriogenology, 21, 699-711.

TSAI-MORRIS C. H., GHOSH M., HIRSHFIELD A. N., WISE P. M., BRODIE A. M. H., 1983. Inhibition of ovarian aromatase by prolactin in vitro. Biol. Reprod., 29, 342-346.

TUCKER H. A., 1971. Hormonal response to milking. J. anim. Sci., 32 (Suppl.), 137-141.

TUCKER H. A., 1982. Seasonality in cattle. Theriogenology, 17, 53-59.

WAGNER W. C., OXENREIDER S. L., 1972. Adrenal function in the cow. Diurnal changes and the effects of lactation and neurohypophyseal hormones. J. anim. Sci., 32, Suppl. 1, 1-16.

WAGNER W. C., LI P. S., 1982. Influence of adrenal corticosteroids on postpartum pituitary and ovarian function, 123-147. In KARG H., SCHALLENBERGER E., Factors influencing fertility in the postpartum cow. Martinus Nijhoff, The Hague, The Netherlands.

WALTERS D. L., KALTENBACH T. G., DUNN T. G., SHORT R. E., 1982a. Pituitary and ovarian function in postpartum beef cows. 1. Effect of suckling on serum and follicular fluid hormones and follicular gonadotropin receptors. Biol. Reprod., 26, 640-646.

WALTERS D. L., SHORT R. E., CONVEY E. M., STAIGMULLER R. B., DUNN T. C., KALTENBACH C. C., 1982b. Pituitary and ovarian function in postpartum beef cows. 2. Endocrine changes prior to ovulation in suckled and non suckled postpartum cows compared to cycling cows. Biol. Reprod., 26, 647-654.

WALTERS D. L., SHORT R. E., CONVEY E. M., STAIGMULLER R. B., DUNN T. G., KALTEN BACH C. C., 1982c. Pituitary and ovarian function in postpartum beef cows. 3. Induction of estrus, ovulation and luteal function with intermittent small-dose injections of $\mathrm{GnRH}$. Biol. Reprod., 26, 655-662.

WALTERS D. L., SMITH M. F., HARMS P. G., WILTBANK J. N., 1982d. Effects of steroids and/or $48 \mathrm{hr}$ calf removal on serum luteinizing hormone concentrations in anoestrous beef cows. Theriogenologv, 18, 349-356.

WATSON E. D., 1984. Plasma concentrations of PGFM in two cows with and in two cows without postpartum endometritis. Vet. Rec., 114, 479-480.

WEBB R., LAMMING G. E., HAYNES N. B., HAFS H. D., MANNS J. G., 1977. Response of cyclic and postpartum suckled cows to injections of synthetic LH-RH. J. Reprod. Fert., 50, 203-210.

WEBB R., LAMMING G. E., HAYNES N. B., FOXCROFT G. R., 1980. Plasma progesterone and gonadotropin concentrations and ovarian activity in postpartum dairy cows. J. Reprod. Fert., 59, 133-143.

WETTEMANN R. P., TURMAN E. J., WYATT R. D., TOTUSEK R., 1978 . Influence of suckling intensity on reproductive performance of range cows. J. anim. Sci, 47, 342-346.

WHITMAN R. W., REMMENGA E. E., WILTBANK J. N., 1975. Weight change, condition and beef cow reproduction. J. anim. Sci., 41, 387 (Abstr.).

WILLIAMS G. L., RAY. D. E., 1980. Hormonal and reproductive profiles of early postpartum beef heifers after prolactin suppression or steroid-induced luteal function. J. anim. Sci, 50, 906917.

WILLIAMS G. L., PETERSEN B. J., TILTON J. E., 1982. Pituitary and ovarian responses of postpartum dairy cows to progesterone priming and single or double injections of gonadotropinreleasing hormone. Theriogenology, 18, 561-572.

WILLIAMS G. L., KIRSH J. D., POST G. R., TILTON J. E., SLANGER W. D., 1984. Evidence against chronic teat stimulation as an autonomous effector of diminished gonadotropin release in beef cows. J. anim. Sci., 59, 1060-1069.

WILTBANK J. N., COOK A. C., 1958. The comparative reproductive performance of nursed cows and milked cows. J. anim. Sci., 17, 640-648.

WILTBANK J. N., ROWDEN W. W., INGALLS J. E., GREGORY K. E., KOCH R. M., 1962. Effect of energy level on reproductive phenomena of mature Hereford cows. J. anim. Sci., 21, 219225.

WILTBANK J. N., ROWDEN W. W., INGALLS J. E., ZIMMERMAN D. R., 1964 . Influence of postpartum energy level on reproductive performance of Hereford cows restricted in energy intake prior to calving. J. anim. Sci, 23, 1049-1053. 
YEN S. S. C., VANDENBERG G., SILER T. M., 1974. Modulation of pituitary responsiveness to LRF by estrogen. J. clin. Endocrin. Metab., 39, 170-177.

ZAIED A. A., GARVERICK H. A., BIERSCHWAL C. J., ELMORE R. G., YOUGQUIST R. S., SHARP A. J., 1980. Effect of ovarian activity and endogenous reproductive hormones on GnRH-induced ovarian cycles in postpartum dairy cows. J. anim. Sci, 50, 508-513.

ZALESKY D. D., DAY M. L., GARCIA-WINDER M., IMAKAWA K., KITTOK R. J., D'OCCHIO M. J., KINDER J. E., 1984. Influence of exposure to bulls on resumption of estrous cycles following parturition in beef cows. J. anim. Sci, 59, 1135-1139.

ZOLMAN J., CONVEY E. M., BRITT J. H., HAFS H. D., 1974. Relationships between the luteinizing hormone response to gonadotropin-releasing hormone and endogenous steroids. J. anim. Sci., 39, 355-359. 